\title{
International Studies on Childhood and Adolescence (ISCA)
}

The aim of the ISCA series is to publish theoretical and methodological studies on the social, cultural, economic, and health situation of children and adolescents.

Almost all countries worldwide report increased risks and problems in the development of children and adolescents. Many pedagogic, psychosocial, and medical institutes as well as education and training centers are trying to help children and adolescents deal with problematic situations. They step in to help with existing difficulties (intervention) or to avoid problems in advance (prevention). However, not enough is known about the causes and backgrounds of the difficulties that arise in the life course of children and adolescents. There is still insufficient research on the effectiveness and consequences of prevention measures and intervention in families, pre-school institutions, schools, youth service, youth welfare, and the criminal justice system.

The ISCA series addresses these issues. An interdisciplinary team of editors and authors focusses on the publications on theoretical, methodological, and practical issues in the above mentioned fields. The whole spectrum of perspectives is considered: analyses rooted in the sociological as well as the psychological or medical and public health tradition, from an economic or a political science angle, mainstream as well as critical contributions.

The ISCA series represents an effort to advance the scientific study of childhood and adolescence across boundaries and academic disciplines.

\section{Editorial Board}

Prof. Klaus Hurrelmann (Coord.), Faculty of Health Sciences, University of Bielefeld, Postfach 1001 31, D-33501 Bielefeld, Tel.: (49-521)-106-3834, Fax: (49-521)-106-2987; Prof. Günter Albrecht, Faculty of Sociology; Prof. Michael Brambring. Faculty of Psychology; Prof. Detlev Frehsee: Faculty of Law; Prof. Wilhelm Heitmeyer, Faculty of Pedagogics; Prof. Alois Herlth, Faculty of Sociology; Prof. Dietrich Kurz, Faculty of Sports Sciences; Prof. Franz-Xaver Kaufmann, Faculty of Sociology; Prof. HansUwe Otto, Faculty of Pedagogics; Prof. Klaus-Jürgen Tillmann, Faculty of Pedagogics; all University of Bielefeld, Postfach 1001 31, D-33501 Bielefeld

\section{Editorial Advisors}

Prof. John Bynner, City University, Social Statistics Research, London, Great Britain; Prof. Manuela du Bois-Reymond, University of Leiden, Faculty of Social Sciences, Leiden. The Netherlands; Prof. Marie Choquet, Institut National de la Santé, Paris, France; Prof. David P. Farrington, University of Cambridge, Institute of Criminology, Cambridge, Great Britain: Prof. James Garbarino, Erikson Institute, Chicago, USA: Prof. Stephen F. Hamilton, Cornell Human Development Studies, Ithaca, USA; Prof. Rainer Hornung, University of Zurich. Institute of Psychology, Zurich, Switzerland; Prof. Gertrud Lenzer, Graduate School CUNY, New York, USA; Prof. Wim Meeus, University of Utrecht, Faculty of Social Sciences, Utrecht, The Netherlands; Prof. Ira M. Schwartz, University of Pennsylvania, School of Social Work, Philadelphia, USA; Prof. Giovanni B. Sgritta, University of Rome, Department of Demographic Sciences, Rome, Italy: Prof. Karl R. White, Utah State University, Logan, USA 


\section{Eating Disorders in Adolescence}

Anorexia and Bulimia Nervosa

Edited by

Hans-Christoph Steinhausen

$\mathrm{W}$
$\mathrm{DE}$
$\mathrm{G}$

Walter de Gruyter · Berlin · New York 1995 
Hans-Christoph Steinhausen

M.D., Ph.D., Professor, Psychiatrische Universitäts-Poliklinik für Kinder und Jugendliche, Zürich, Switzerland

With 25 figures and 43 tables

Library of Congress Cataloging-in-Publication Data

Eating disorders in adolescence ; anorexia and bulimia nervosa / edited by Hans-Christoph Steinhausen,

XVIII, 374 p. $17 \times 24 \mathrm{~cm}$. -- (International studies on child-

hood and adolescence : 3 )

Includes index.

ISBN 3-11-014347-X (alk. paper)

1. Eating disorders in adolescence. 1. Series.

[DNLM: I. Eating Disorders -- in adolescence.

WM 175 E14819 1995]

RJ506.E18E28 1995

616.85'26'00835--dc20

DNLM/DLC

for Library of Congress

95-547

CIP

Dic Deutsche Bihliothek - Catuloging-in-Publicution Data

Eating disorders in adolescence : anorexia and bulimia nervosa / ed. by Hans-Christoph Steinhausen. - Berlin : New York : de Gruyter, 1995

(International studies on childhood and adolescence : 3)

ISBN 3-11-014347-X

NE: Steinhausen, Hans-Christoph [Hrsg.]; GT

(0) Printed on acid-free paper which falls within the guidelines of the ANSI to ensure permanence and durability.

(c) Copyright 1995 by Walter de Gruyter \& Co., D-10785 Berlin

All rights reserved, including those of translation into foreign languages. No part of this book may be reproduced or transmitted in any form or by any means, electronic or mechanical, including photocopy, recording or any information storage and retrieval system, without permission in writing from the publisher. Printed in Germany Printing: WB-Druck GmbH, Rieden am Forggensee. Binding: D. Mikolai GmbH, Berlin. Cover Design: Johannes Rother, Berlin. 